\title{
Estimation of Serum Hepcidin and Ferritin in Patients with Chronic Liver Disease
}

\author{
Safia Mahmoud Mohamed ${ }^{1}$, Amal Abd el-Aleem Morsy ${ }^{2}$, \\ Nessren Mohamed Bahaa El-Deen Mohamed ${ }^{1 *}$, Aya Ragab Mohamed ${ }^{1}$ \\ Departments of ${ }^{1}$ Tropical Medicine and ${ }^{2}$ Clinical Pathology, \\ Faculty of Medicine for Girls, Al-Azhar University \\ *Corresponding author: Nessren Mohamed Bahaa-El-Deen, E-Mail: m_moez71@yahoo.com, Phone: 01003703546
}

\begin{abstract}
Background: Hepatitis $\mathrm{C}$ virus affect iron metabolism leading to iron overload which associated with liver damage.

Aim: estimation of the level of serum hepcidin and ferritin in chronic hepatitis $\mathrm{C}$, cirrhosis and hepatocellular carcinoma on top of hepatitis C.

Methods: this study was conducted on 60 Egyptian patients (study group); Group I comprise 20 patients with chronic HCV infection, Group II comprise 20 patients with HCV cirrhosis, Group III comprise 20 patients with $\mathrm{HCC}$ due to HCV infection, and also, control group comprise 20 apparently healthy individuals. All patients and control were subjected to history taking, clinical examination, abdominal ultrasound, computed tomography on abdomen. Laboratory investigations include complete blood picture, renal function tests, liver function tests, and viral hepatitis marker. Antinuclear antibody, Alpha-fetoprotein, serum iron, serum ferritin and serum hepcidin.

Results: There was highly significant decreased in S. iron level in group I, II and III in comparison to control group $(\mathrm{p}=0.000)$. There was highly significant increase in S. Ferritin level in group II and group III in comparison to control group and in group III in comparison to group I. Also, there was significant increase in S. Ferritin level in group II in comparison to group I. There was highly significant decrease in S. hepcidin level in group II and group III in comparison to control group, in group II and group III in comparison to group I and in group III in comparison to group II. S. Hepcidin has highly significant negative correlation with S. ferritin in group I, II and III.
\end{abstract}

Conclusion: Low levels of serum iron, ferritin and hepcidine were observed in HCV cirrhotic and HCC compared to control group.

Keywords: HCV, cirrhosis, serum iron, serum ferritin, serum hepcidin.

\section{INTRODUCTION}

Hepatitis $\mathrm{C}$ virus infection is a major global health challenge, it is estimated that more than 80 million people are chronically infected worldwide, with 3-4 million new infection and 350,000 death occurring each year because of $\mathrm{HCV}$ related complications $^{(\mathbf{1})}$

The Egypt Demographic and Health Surveys (EDHS) measured antibody prevalence among the adult populations aged 15-59 years at $14.7 \%$ in $2009^{(2)}$ and $10.0 \%$ in $2015^{(3)}$.

Hepatitis $\mathrm{C}$ virus remains the leading cause of chronic liver disease, accounting for $50 \%$ to $70 \%$ of primary liver cancers ${ }^{(4)}$. The incidence of chronic liver disease is increasing ${ }^{(5)}$.

Hepatocellular carcinoma (HCC), the most common primary liver represents cancer, the sixth most common cancer worldwide, which results in the third cause of death from cancer per year ${ }^{(\boldsymbol{6})}$. Egypt has rising rates of $\mathrm{HCC}^{(7)}$.

Hepcidin is acysteine - rich circulating bioactive peptide that is predominantly secreted from the liver and excreted in the urine ${ }^{(8)}$. It also cause a release of iron by macrophages and hepatocytes ${ }^{(9)}$.

Hepcidin controls plasma iron concentration and tissue distribution of iron. It inhibits intestinal iron absorption by enterocytes in the duodenum through its binding to ferroportin and inducing its internalization and degradation (10). Theses mechanisms result in decrease of serum iron concentration and increased intracellular iron content ${ }^{(\mathbf{1 1})}$. The liver is the main iron storage organ a third of the body's total iron is deposited in hepatocyte, in the portal tracts, sinusoidal mesenchymal cells and reticuloendothelial cells ${ }^{(\mathbf{1 2})}$. It also plays a fundamental role in iron metabolism, as both transferrin (the main transporting protein) and ferritin (the major storage protein) are synthesized here ${ }^{(\mathbf{1 3})}$.

\section{AIM OF THE WORK}

Estimation of the level of serum hepcidin and ferritin in chronic hepatitis $\mathrm{C}$, cirrhosis and hepatocellular carcinoma on top of hepatitis $\mathrm{C}$. 


\section{PATIENTS AND METHODS}

This case-control study was conducted on sixty Egyptian patients with chronic liver disease (CHC) according to clinical, laboratory and imaging examination and twenty apparently healthy control subjects matched with the patients according to age and sex were included as a control group. They were selected from those attended to Tropical Medicine department, Al Zahraa University hospital from March 2017 to August 2017.

The study was approved by the Ethics Board of Al-Azhar University.

Group I Chronic HCV ( $\mathrm{n}=20)$. Group II Chronic HCV Cirrhotic Patients $(n=20)$. Group III HCC Due To HCV Infection $(n=20)$. Control group, this group comprise 20 apparently healthy volunteers.

\section{Inclusion criteria}

Adult patients of both sexes with seropositivity of HCV Ab.

\section{Exclusion criteria}

Associated Hepatitis B virus infection, family history of haemochromatosis, hepatic tumors unrelated to $\mathrm{HCV}$, hemolytic diseases, and patient with recent history of bleeding or blood transfusion and autoimmune liver disease.

After giving an informed consent, all the individuals included in this study were subjected to the following: full history taking, symptoms of upper and lower GIT symptoms (as abdominal pain, dyspepsia, haematemesis and melena), liver cell failure (Jaundice, ascites, oedema of lower limbs), bleeding tendency (epistaxis, bleeding gums \& skin bruises), and symptoms suggestive hepatic encephalopathy (HE) (inverted sleep rhythm, flapping tremors, foetorhepaticus, confusion \& personality changes).

\section{Laboratory investigations}

All study groups were subjected to the following; complete blood count (CBC), prothrombin time (PT) and internationl Normalized Ratio (INR). Liver Function testes including: Asparate amino transferase (AST), Alanine amino transferase (ALT), Alkaline Phosphatase (ALP), serum bilirubin, and serum albumin. Kidney function testes including seum urea and creatinin. Assay of Alpha feto-protein (AFP) and Antinuclear -antibody (ANA). Assay of serum iron and ferritin using Enzym Linked Immuno Assay (ELISA). Assay of serum hepcidin using fully automated photometric analyzer Cobas C3 11 .

Imaging: all study groups were subjected to ultrasonography and triphasic CT on the abdomen.

\section{Statistical analysis}

Statistical analysis was performed by using the Statistical Package for Social Science (SPSS) program (version 23).

Parametric data was summarized using mean $\pm \mathrm{SD}$, whereas non-parametric data was summarized as median, and interquartile range (IQR) for quantitative variables, while frequency and percentages were used for qualitative variables. The p-value was considered significant as the following:

$\mathrm{P}>0.05$ : Non significant.

$P<0.05$ : Significant.

$\mathrm{P}<0.01$ : Highly significant.

\section{RESULTS}

This study was conducted on 60 patients; 30 males and 30 females. Age of the patients was ranged from $40-68$ years.

Table (1): Comparison between the studied groups regarding age and sex

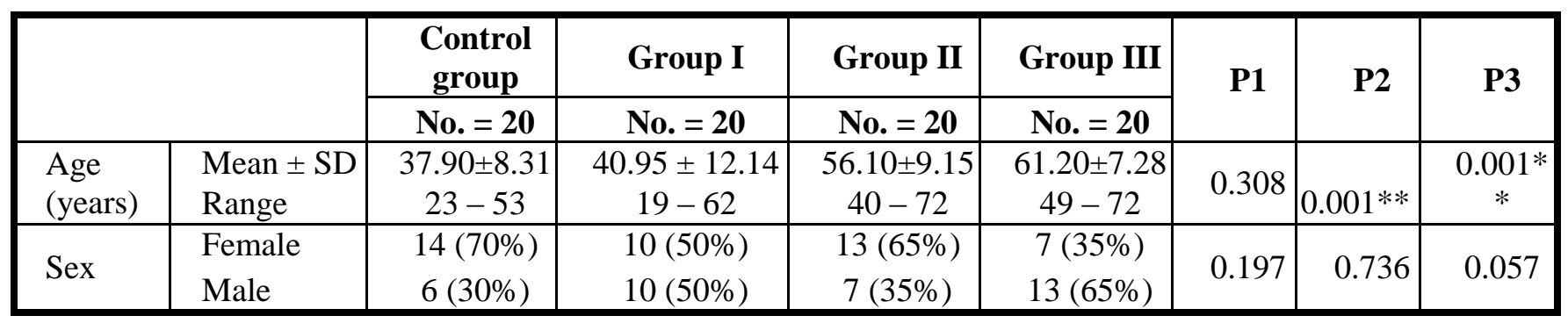

$\mathrm{P}$-value $>0.05$ : Non-significant, $\mathrm{P}$-value $<0.05$ : Significant, $\mathrm{P}$-value $<0.01$ : Highly significant

P1: Control group vs group I, P2: Control group vs group II, P3: Control group vs group III 
Safia Mohamed et al.

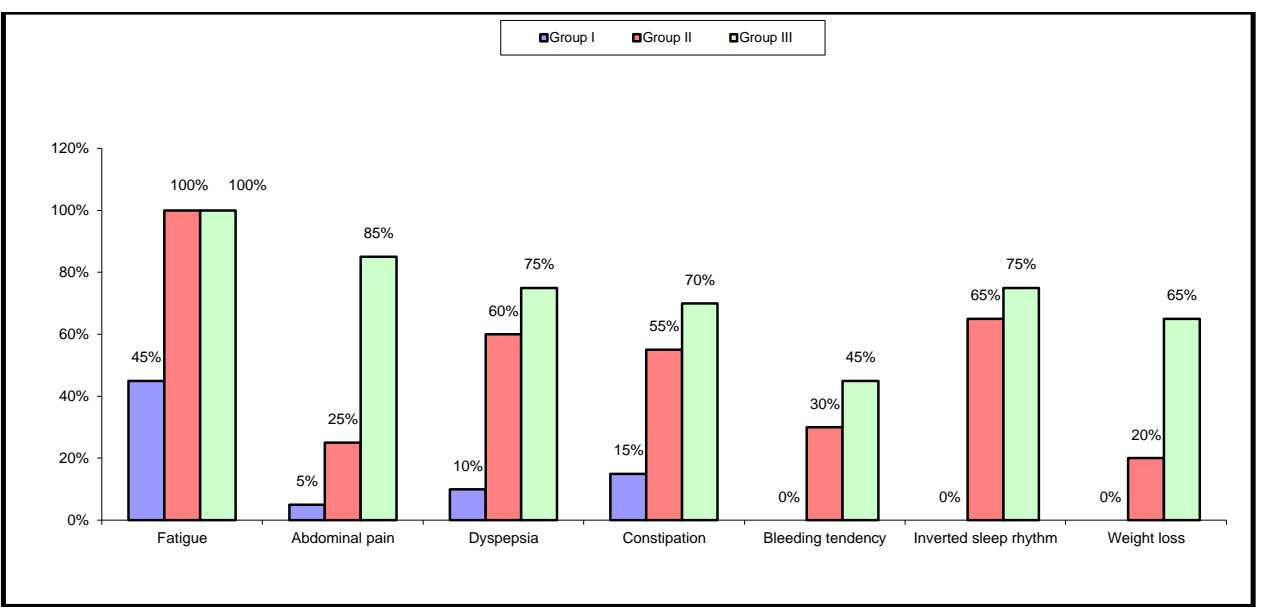

Figure (1): Comparison between patients groups as regard symptoms.

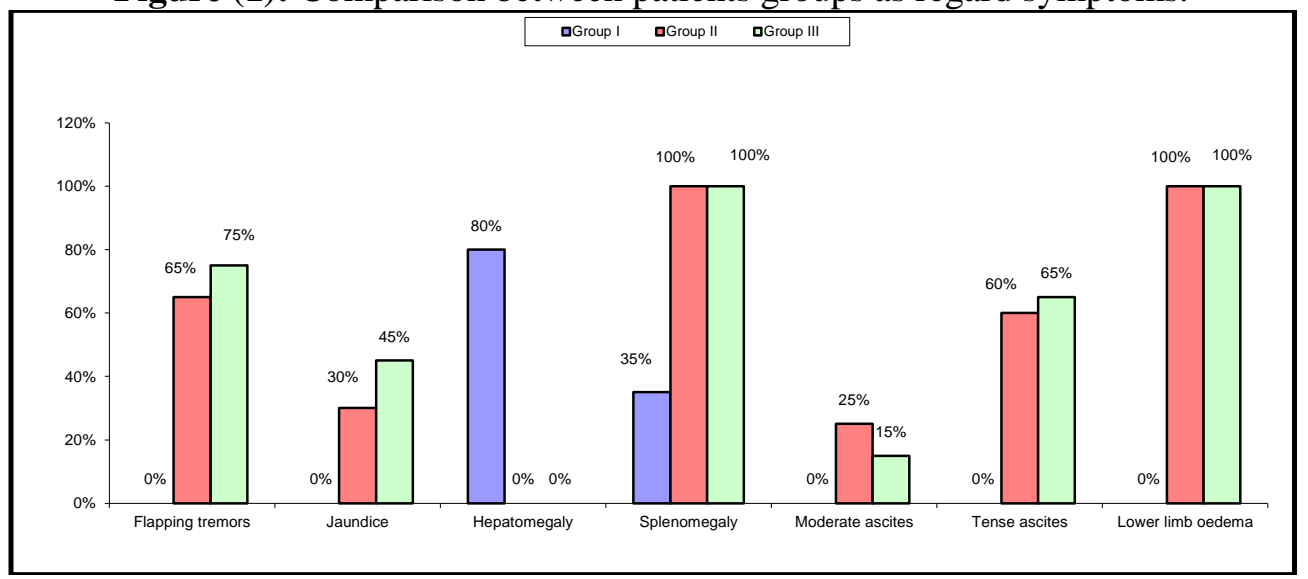

Figure (2): Comparison between patients groups as regard signs.

Table (2): Results of abdominal ultrasound among the patients groups

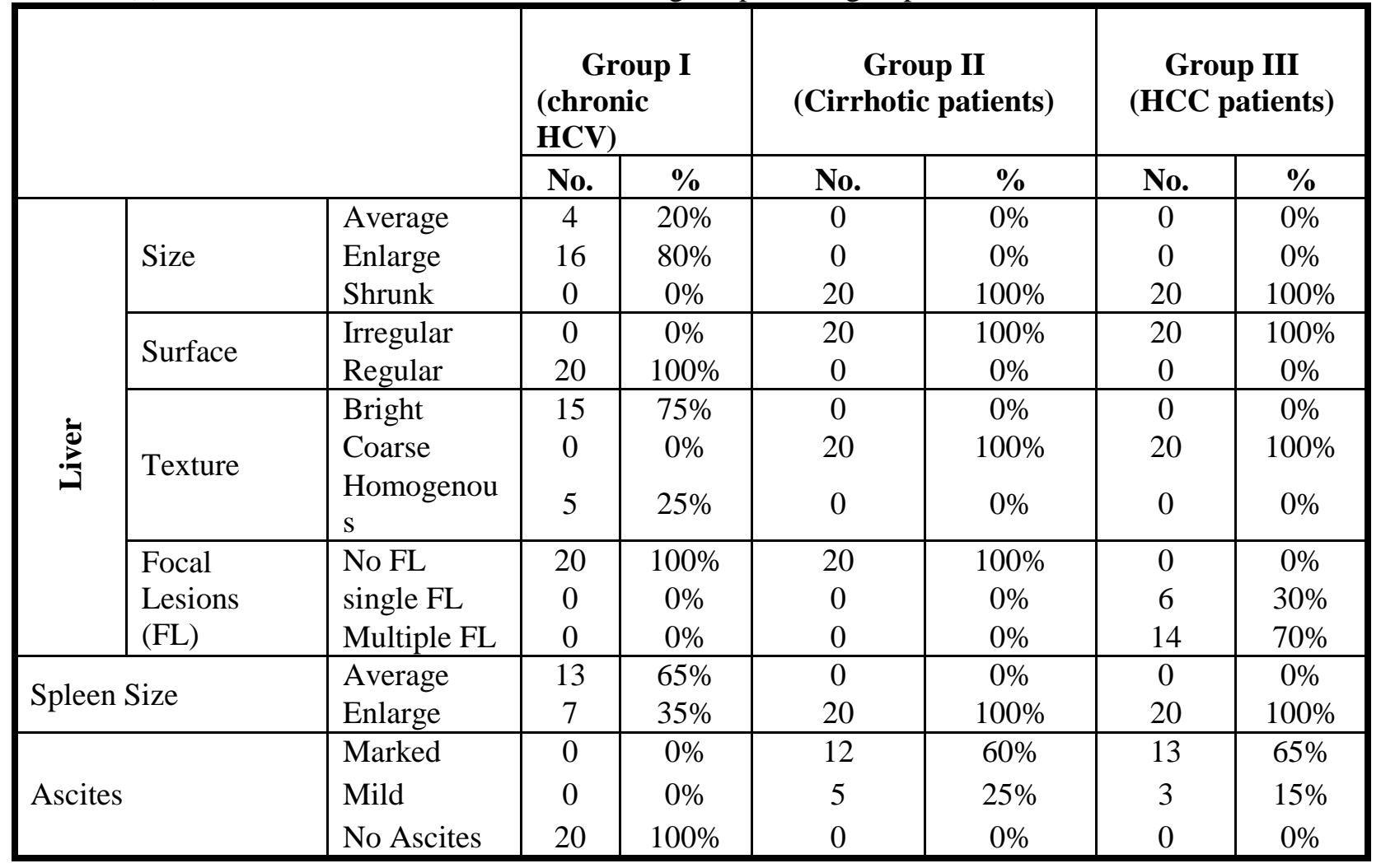


Table (3): Results of triphasic abdominal CT in HCC (Group III) patients.

\begin{tabular}{|l|c|c|}
\hline \multirow{2}{*}{ CT } & \multicolumn{2}{|c|}{$\begin{array}{c}\text { Group III (N=20) } \\
\text { (HCC patients) }\end{array}$} \\
\cline { 2 - 3 } & $\mathbf{N}$ & \% \\
\hline N of Fl & 6 & $30.0 \%$ \\
Single & 14 & $70.0 \%$ \\
Multiple & & \\
\hline Size & 11 & $55.0 \%$ \\
$>5$ & 9 & $45.0 \%$ \\
$<5$ & & \\
\hline Portal vein & 20 & $100 \%$ \\
Patent & 0 & $0.0 \%$ \\
Thrombosed & 0 & $0.0 \%$ \\
\hline Lymph node involvement & 0 & $0.0 \%$ \\
\hline Secondaries & & \\
\hline
\end{tabular}

Table (4): Results of blood picture in the studied groups

\begin{tabular}{|l|l|c|c|c|c|}
\hline \multicolumn{2}{|c|}{} & $\begin{array}{c}\text { Control } \\
\text { Group }\end{array}$ & $\begin{array}{c}\text { Group I } \\
\text { (chronic } \\
\text { HCV) }\end{array}$ & $\begin{array}{c}\text { Group II } \\
\text { (cirrhotic } \\
\text { patients) }\end{array}$ & $\begin{array}{c}\text { Group III } \\
\text { (HCC patients) }\end{array}$ \\
\cline { 3 - 6 } & No. = 20 & No. $=\mathbf{2 0}$ & No. $=\mathbf{2 0}$ & No. $=\mathbf{2 0}$ \\
\hline WBCs $\left(10^{3} / \mathrm{uL}\right)$ & Mean \pm SD & $7.00 \pm 1.82$ & $4.87 \pm 1.65$ & $5.09 \pm 1.15$ & $4.81 \pm 1.21$ \\
\hline RBCs $\left(10^{6} / \mathrm{uL}\right)$ & Mean \pm SD & $4.74 \pm 0.31$ & $4.65 \pm 0.63$ & $3.69 \pm 0.63$ & $3.79 \pm 0.64$ \\
\hline HB g/dl & Mean \pm SD & $13.58 \pm 1.20$ & $12.60 \pm 1.72$ & $11.97 \pm 1.23$ & $10.74 \pm 1.05$ \\
\hline Platelet $\left(10^{3} \mathrm{uL}\right)$ & Mean \pm SD & $263.40 \pm 8.82$ & $181.10 \pm 6.87$ & $74.57 \pm 4.91$ & $79.80 \pm 4.99$ \\
\hline ESR mm/h & Median $(\mathrm{IQR})$ & $20(15-23)$ & $20(15-37.5)$ & $51.5(22.0-86)$ & $58.5(50-102.5)$ \\
\hline
\end{tabular}

Table (5): Comparison of blood picture among the studied groups

\begin{tabular}{|c|c|c|c|c|c|}
\hline Parameters & $\begin{array}{c}\text { WBCs } \\
\left(10^{3} / \mathrm{uL}\right)\end{array}$ & $\begin{array}{c}\text { RBCs } \\
(10 * 6 / u L)\end{array}$ & HB g/dl & $\begin{array}{l}\text { Platelet } \\
\left(10^{3} \mathrm{uL}\right)\end{array}$ & $\begin{array}{c}\mathrm{ESR} \\
\mathrm{mm} / \mathrm{h}\end{array}$ \\
\hline P1 & $0.004^{* *}$ & 0.802 & $0.022 *$ & $0.001 * *$ & 0.452 \\
\hline P2 & $0.010^{*}$ & $0.005^{* *}$ & $0.001 * *$ & $0.001^{* *}$ & $0.001^{* *}$ \\
\hline P3 & $0.003^{* *}$ & $0.001 * *$ & $0.001 * *$ & $0.001 * *$ & $0.001 * *$ \\
\hline P4 & 0.775 & $0.023^{*}$ & 0.148 & $0.001 * *$ & $0.008^{* *}$ \\
\hline P5 & 0.933 & $0.001 * *$ & $0.001 * *$ & $0.001 * *$ & $0.001 * *$ \\
\hline P6 & 0.711 & 0.562 & $0.006^{* *}$ & 0.762 & 0.083 \\
\hline
\end{tabular}

P1: Control group vs group I, P2: Control group vs group II, P3: Control group vs group III P4: Group I vs group II, P5: Group I vs group III, P6: Group II vs group

Table (6): Results of liver function tests and AFP in the studied groups

\begin{tabular}{|c|c|c|c|c|c|}
\hline & $\begin{array}{c}\text { Control } \\
\text { Group }\end{array}$ & $\begin{array}{c}\text { Group I } \\
\text { (chronic HCV) }\end{array}$ & $\begin{array}{c}\text { Group II } \\
\text { (Cirrhotic patients) } \\
\end{array}$ & $\begin{array}{c}\text { Group III } \\
\text { (HCC patients) }\end{array}$ \\
\hline & & No. $=20$ & No. $=20$ & No. $=20$ & No. $=20$ \\
\hline ALT (U/L) & Mean \pm SD & $24.15 \pm 4.57$ & $29.20 \pm 5.71$ & $29.95 \pm 1.08$ & $31.05 \pm 5.72$ \\
\hline AST (U/L) & Mean \pm SD & $23.50 \pm 5.62$ & 31.40 & $52.50 \pm 2.31$ & $56.65 \pm 9.38$ \\
\hline Albumin (g/dl) & Mean \pm SD & $4.19 \pm 0.45$ & $4.00=$ & $2.60 \pm 0.58$ & 0.46 \\
\hline ALP U/L & Mean \pm SD & $73.95 \pm 19.66$ & $31.60 \pm$ & $97.55 \pm 6.49$ & \pm 6.76 \\
\hline $\begin{array}{l}\begin{array}{l}\text { Bilirubin T } \\
(\mathrm{mg} / \mathrm{dl})\end{array} \\
\end{array}$ & Median (IQR) & $0.5(0.35-0.8)$ & $0.55(0.4-0.75)$ & $1.9(1.15-3.2)$ & $1.9(1.45-2.15)$ \\
\hline $\mathrm{PC}$ & Mean \pm SD & $89.95 \pm 9.62$ & $86.75 \pm 11.13$ & $48.10 \pm 8.10$ & $54.88 \pm 9.33$ \\
\hline AFP ng/ml & Median (IQR) & $6(4.35-8.05)$ & $7.25(4.65-9.0)$ & $7.0(4.5-10.1)$ & $7.5(310.5$ \\
\hline
\end{tabular}


Table (7): Comparison of liver function tests and AFP among the studied groups

\begin{tabular}{|c|c|c|c|c|c|c|c|}
\hline Parameters & $\begin{array}{c}\text { ALT } \\
\text { (U/L) }\end{array}$ & $\begin{array}{c}\text { AST } \\
\text { (U/L) }\end{array}$ & $\begin{array}{c}\text { Albumin } \\
\text { (g/dl) }\end{array}$ & $\begin{array}{c}\text { ALP } \\
\text { (U/L) }\end{array}$ & $\begin{array}{c}\text { Bilirubin } \\
\text { T }\end{array}$ & PC & $\begin{array}{c}\text { AFP } \\
\text { ng/ml }\end{array}$ \\
\hline P1 & 0.227 & 0.148 & 0.21 & 0.334 & 0.753 & 0.296 & 0.514 \\
\hline P2 & 0.166 & $0.001^{* *}$ & $0.000^{* *}$ & $0.004^{* *}$ & $0.004^{* *}$ & $0.001^{* *}$ & 0.357 \\
\hline P3 & 0.059 & $0.001^{* *}$ & $0.000^{* *}$ & $0.001^{* *}$ & $0.001^{* *}$ & $0.001^{* *}$ & $0.001^{* *}$ \\
\hline P4 & 0.869 & $0.001^{* *}$ & $0.000^{* *}$ & 0.061 & $0.001^{* *}$ & $0.001^{* *}$ & 0.797 \\
\hline P5 & 0.609 & $0.00^{* *}$ & $0.000^{* *}$ & $0.001^{* *}$ & $0.001^{* *}$ & $0.001^{* *}$ & $0.001^{* *}$ \\
\hline P6 & 0.761 & 0.500 & 0.973 & $0.001^{* *}$ & 0.684 & $0.035^{*}$ & $0.001^{* *}$ \\
\hline
\end{tabular}

P1: Control group vs group I, P2: Control group vs group II, P3: Control group vs group III

P4: Group I vs group II, P5: Group I vs group III, P6: Group II vs group

Table (8): Results of serum iron, serum ferritin and hepcidinin the studied groups

\begin{tabular}{|c|c|c|c|c|c|}
\hline \multicolumn{2}{|c|}{} & $\begin{array}{c}\text { Control } \\
\text { Group }\end{array}$ & $\begin{array}{c}\text { Group I } \\
\text { (chronic HCV) }\end{array}$ & $\begin{array}{c}\text { Group II } \\
\text { (Cirrhotic patients) }\end{array}$ & $\begin{array}{c}\text { Group III } \\
\text { (HCC patients) }\end{array}$ \\
\cline { 3 - 6 } & No. $=\mathbf{2 0}$ & No. $=\mathbf{2 0}$ & No. $=\mathbf{2 0}$ & No. = 20 \\
\hline $\begin{array}{c}\text { S.Iron } \\
(\mathrm{ug} / \mathrm{dl})\end{array}$ & Mean \pm SD & $117.10 \pm 23.70$ & $84.25 \pm 28.69$ & $88.45 \pm 47.71$ & $65.45 \pm 15.36$ \\
\hline $\begin{array}{c}\text { S.Ferritin } \\
(\mathrm{ng} / \mathrm{ml})\end{array}$ & Median (IQR) & $35.4(26.8-46)$ & $57.75(26.75-77.8)$ & $93.1(45.95-137.5)$ & $119(51.8-191.7)$ \\
\hline $\begin{array}{c}\text { S.Hepcidin } \\
(\mathrm{ng} / \mathrm{ml})\end{array}$ & Median (IQR) & $3.12(2.75-3.3)$ & $2.75(2.29-3.0)$ & $1.15(1.05-1.8)$ & $0.8(0.55-1.05)$ \\
\hline
\end{tabular}

Table (9): Comparison of S.iron, ferritin and hepcidin among the studied groups

\begin{tabular}{|c|c|c|c|}
\hline Parameters & S.Iron $(\mathrm{ug} / \mathrm{dl})$ & Ferritinng/ml & S.Hepcidinng/ml \\
\hline P1 & $0.001^{* *}$ & 0.062 & 0.058 \\
\hline P2 & $0.005^{* *}$ & $0.001^{* *}$ & $0.001^{* *}$ \\
\hline P3 & $0.001^{* *}$ & $0.001^{* *}$ & $0.001^{* *}$ \\
\hline P4 & 0.692 & $0.035^{*}$ & $0.001^{* *}$ \\
\hline P5 & 0.08 & $0.009^{* *}$ & $0.001^{* *}$ \\
\hline P6 & 0.053 & 0.245 & $0.004^{* *}$ \\
\hline
\end{tabular}

P1: Control group vs group I, P2: Control group vs group II, P3: Control group vs group III

P4: Group I vs group II, P5: Group I vs group III, P6: Group II vs group

Table (10): Cut off point, Sensitivity, Specificity, PPV, NPV, AUC for Serum Hepcidin Level and Serum Ferritin Level in Differentiation Between Control Group and Group II

\begin{tabular}{|c|c|c|r|r|l|l|}
\hline & $\begin{array}{r}\text { Cut off } \\
\text { point }\end{array}$ & AUC & Sensitivity & Specificity & + PV & -PV \\
\hline S. hepcidin & $\leq 2.2$ & 1.000 & 100.00 & 100.00 & 100.00 & 100.00 \\
\hline S. ferritin & $>47.7$ & 0.880 & 75.00 & 85.00 & 83.3 & 77.3 \\
\hline
\end{tabular}




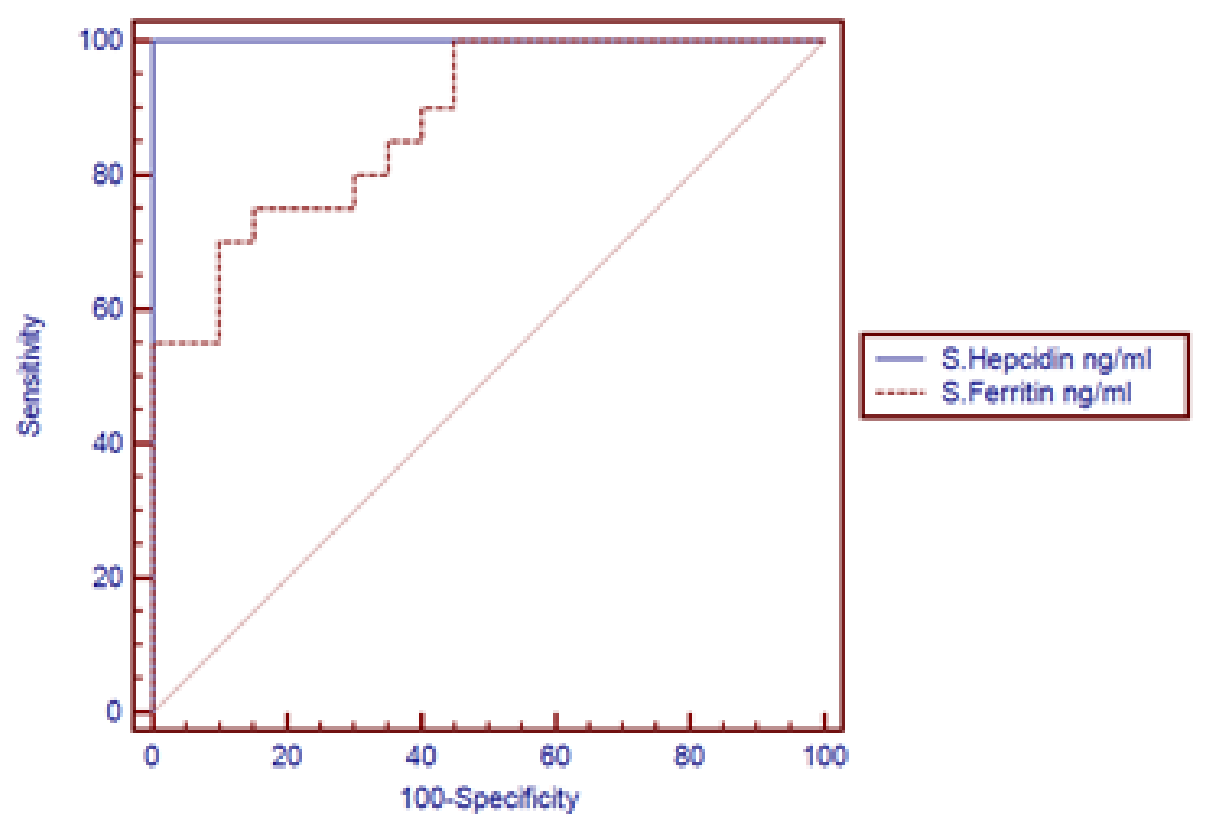

Figure (2): ROC curve for serum hepcidin level and serum ferritin level in differentiation between control group and group II.

Table (11): Cut off Point, Sensitivity, Specificity, PPV, NPV, AUC for Serum Hepcidin Level and Serum Ferritin Level in Differentiation Between Control Group and Group III.

\begin{tabular}{|c|r|r|r|r|r|r|}
\hline & Cut off point & AUC & Sensitivity & \multicolumn{1}{|c|}{ Specificity } & +PV & -PV \\
\hline S. hepcidin & $\leq 2.1$ & 1.000 & 100.00 & 100.00 & 100.00 & 100.00 \\
\hline S. ferritin & $>46.6$ & 0.915 & 85.00 & 80.00 & 81.0 & 84.2 \\
\hline
\end{tabular}

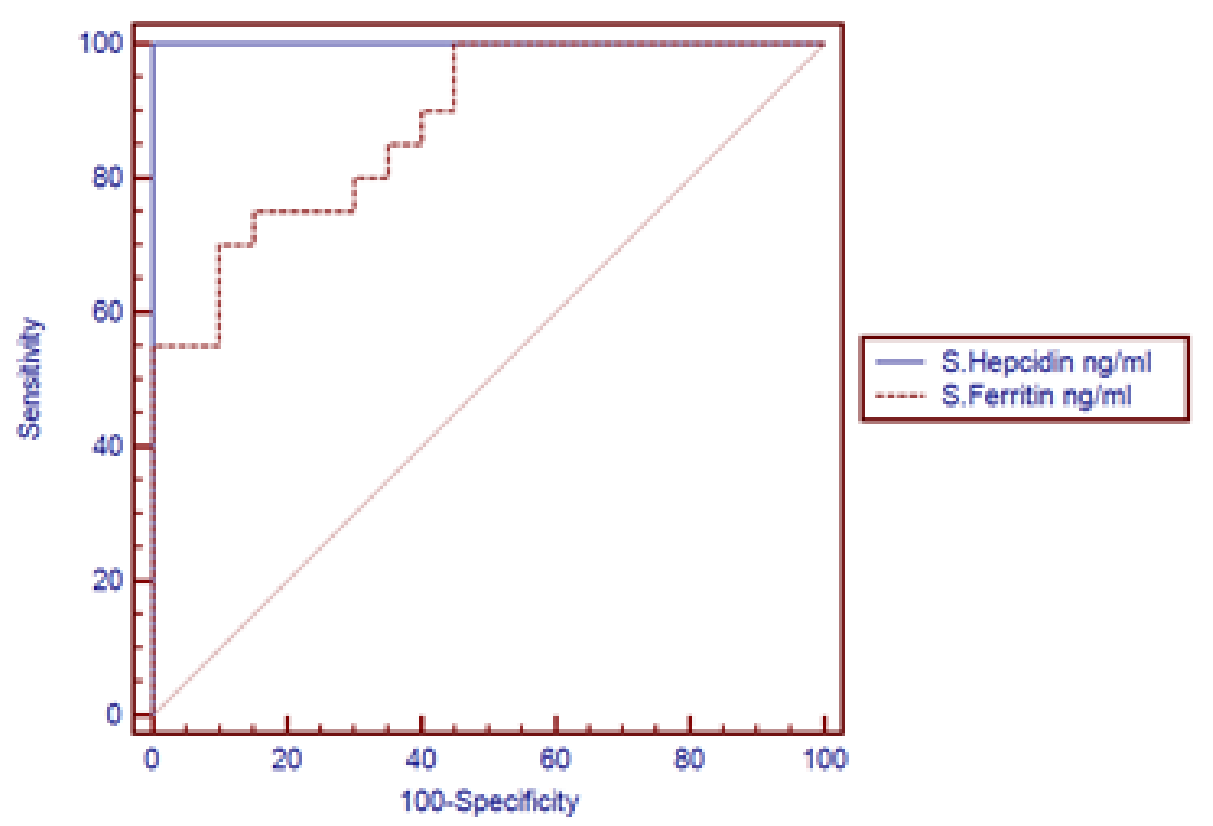

Figure (5): ROC curve for serum hepcidin level and serum ferritin level in differentiation between control group and group III. 


\section{DISCUSSION}

Hepatitis $\mathrm{C}$ virus infection is one of the main causes of chronic liver disease worldwide ${ }^{(4)}$.The longterm hepatic impact of $\mathrm{HCV}$ infection is highly variable, from minimal changes to chronic hepatitis, fibrosis, and cirrhosis with or without hepatocellular carcinoma. The number of chronically infected persons worldwide may be approximately 177 million ${ }^{(14)}$.

Although the causative factor responsible for the initiation of hepatic disease processes in patients with chronic hepatitis $\mathrm{C}(\mathrm{CHC})$ is a single insult, i.e $\mathrm{HCV}$ infection, it has become increasingly evident that the involvement of cofactors is critical in determining disease progression. Importantly, CHC often appears to be associated with disturbances in iron homeostasis, with serum ferritin and hepatic iron stores being elevated in approximately $50 \%$ of patients ${ }^{(\mathbf{1 5})}$.

Because iron is a redox-active metal, catalyzing free radical reactions, and because there is substantial evidence to implicate redox active mechanisms in the pathogenesis of $\mathrm{CHC}$, iron has been highlighted as an important element affecting the natural history of $\mathrm{CHC}^{(15)}$.

Disruption of hepcidin regulation has been postulated as a possible mechanism causing iron overload in acquired conditions, including alcoholic liver disease ${ }^{(\mathbf{1 0})}$ and $\mathrm{CHC}^{(\mathbf{1 7})}$.

Our study was conducted to estimate the level of serum hepcidin and ferritin in chronic hepatitis $\mathrm{C}$ (CHC), cirrhosis and hepatocellular carcinoma (HCC) on top of HCV cirrhosis.

As regard s. iron, there was highly significant decreased in S. iron level in group I, II and III in comparison to control group with no significant differences in group II and group III in comparison to group I and in group II in comparison to group III. These results were in agreement with Marzouk et al. ${ }^{(18)}$; El Lehleh et al. ${ }^{(19)}$ whom found that serum iron was decreased in CLD patients compared to control group.

Also, these results were in agreement with Fujita et al. (20) who found that mild anemic state was a complication in CHC patients. This anemia may also influence the relatively diminished hepatic hepcidin production in these patients.

However, these results were not in agreement with Mohamed et al. ${ }^{(21)}$ who concluded that serum iron was significantly higher in $\mathrm{CHC}$ patients compared to the control group. These discrepancies may be because of the low number of patients and the difference in number of patient groups in stages of liver diseases (Child $A=16$, Child $\mathrm{B}=26$, Child $\mathrm{C}=3$ ).

As regard S. ferritin, there was highly significant increase in S. Ferritin in group II in comparison to control group, in group III in comparison to control group and in group III in comparison to group I. Also, there was significant increase in S. Ferritin in group II in comparison to group I with no significant differences in group I in comparison to control group and in group II in comparison to group III.

Our results were in agreement with Oikonomou et al. ${ }^{(22)}$ who made a study on 192 patients with decompensated cirrhosis. They found that high serum ferritin is associated with worse outcomes in patients with decompensated cirrhosis.

Also, Finkenstedt et al. ${ }^{(23)}$ confirmed in their study that high serum ferritin and transferrin saturation are associated with poor survival in liver cirrhosis.

Also, Pietrangelo et $\boldsymbol{a l}^{(24)}$ reported that serum ferritin was higher in $\mathrm{CHC}$ cirrhotic patients than controls and the levels also correlated with the severity of the disease.

Also, our study was in agreement with Tawfik et al. ${ }^{(25)}$ whom concluded in their study that serum ferritin was higher in HCC patients than nonHCC liver cirrhosis.

As regard serum hepcidin, there was highly significant decrease in S. hepcidin level in group II and group III in comparison to control group, in group II and group III in comparison to group I and in group III in comparison to group II with no significant difference in group I in comparison to control group.

This goes in agreement with Mohamed et al. ${ }^{(26)}$ who stated that Serum hepcidin was significantly lower in $\mathrm{CHC}$ cirrhotic patients than in controls and hepcidin level was significantly decreased in HCC cases than liver cirrhosis, CHC and controls.

Also, our results were in agreement with Terrence et al. ${ }^{(27)}$ who made a study on patients with CLD and healthy controls. Patients were categorized into compensated CLD (with or without cirrhosis) and decompensated CLD. They found that patients with cirrhosis had significantly lower hepcidin and hepcidin-ferritin ratio levels compared with those without cirrhosis and this indicates that this ratio may serve as a potential biomarker for advanced fibrosis and cirrhosis.

Pietrangelo et al. ${ }^{(24)}$ reported a decrease in serum hepcidin along with increased serum ferritin in decompensated cirrhotics and the levels also correlated with the severity of the disease.

Ryan et al. ${ }^{(28)}$ reported a decrease in serum hepcidin and increase in serum ferritin in patients with liver cirrhosis. As hepatic synthetic dysfunction progress in end stage liver disease, reduced production of hepcidin, the liver-derived 
iron regulatory hormone may occur. Hepcidin may be further suppressed by oxidative stress, which is prevalent in decompensated cirrhosis. Deficient hepcidin production leads to hyperferritinaemia and hepatic iron deposition, which would exacerbate the original insult.

Also, our results were in agreement with Fujita et al. ${ }^{(20)}$ who found that hepcidin levels did not differ significantly in CHC patients from those in healthy controls.

However, our results were not in agreement with $\boldsymbol{E} \boldsymbol{l}$ Wakil et al. ${ }^{(29)}$ whom reported significantly increased serum prohepcidin values in $\mathrm{CHC}$ patients compared to the control subjects.

To explain the differences between our results and those of other investigators regarding serum hepcidin and its relation to hepatic pathological changes we can, theoretically, say that in the early phase of $\mathrm{CHC}$, hepcidin may be prominently suppressed by $\mathrm{HCV}$ but as iron accumulates, the negative influence of viral factors may be masked by the positive stimulation of iron while, in advanced stages such as cirrhosis, hepcidin may be further decreased by impaired protein synthesis due to markedly reduced functional hepatic mass.

Also, our results were not in agreement with Girelli et al. ${ }^{(30)}$ whom made study on 81 untreated $\mathrm{CHC}$ patients and 57 controls and concluded that serum hepcidin was reduced in patients with $\mathrm{CHC}$. This may be due to low number of $\mathrm{CHC}$ patients involved in our study (GI=20 patients).

Mohamed et al. ${ }^{(26)}$ reported that that serum hepcidin was lower in HCC patients than non-HCC liver cirrhosis.

In our study, there was highly significant negative correlation with S.ferritin in group I, II and III. This was in agreement with $\mathbf{E l}$ Lehleh et al. ${ }^{(19)}$ whom reported negative correlation between S.ferritin and hepcidin.

As regard the cut off value of S.Hepcidin level in differentiation between control group and group II was $\leq 2.2$, area under curve $=1$, with sensitivity of $100 \%$, specificity of $100 \%$, positive predictive value of $100 \%$ and negative predictive value of $100 \%$. Farid et al. (2012) show that hepcidin can be considered highly valid marker in case of $\mathrm{CHCV}$ infection at cut off $=1.09$, AUC $=0.100, \quad$ sensitivity $=100 \%, \quad$ specificity $=99 \%$, $\mathrm{PPV}=97 \%, \mathrm{NPV}=100 \%$ and accuracy $=100 \%$.

Also, the cut off value of S.ferritin level in differentiation between control group and group II was >47.7, area under curve $=0.880$, with sensitivity of $75 \%$, specificity of $85 \%$, positive predictive value of $83.3 \%$ and negative predictive value of $77.3 \%$. Lange et al. (2011) was define the best cut off value of S.ferritin in discrimination of $\mathrm{HCV}$ cases was $>200$.

We reported the cut off point of S.Hepcidin level in differentiation between control group and group III was $\leq 2.1$, area under curve $=1$, with sensitivity of $100 \%$, specificity of $100 \%$, positive predictive value of $100 \%$ and negative predictive value of $100 \%$. Mohamed et al. (2014)2 was define the best cut off value of $\mathrm{S}$. Hepcidin in discrimination of $\mathrm{HCC}$ cases from other liver diseases was $\leq 42.7$, area under curve $=0.9$, with sensitivity of $92 \%$, specificity of $90 \%$. This disagreement may be due to high number of HCC patients involved in this study $(\mathrm{n}=49)$.

Also, the cut off value of $S$. ferritin level in differentiation between control group and group III was $>46.6$, area under curve $=0.915$, with sensitivity of $85 \%$, specificity of $80 \%$, positive predictive value of $81 \%$ and negative predictive value of $84.2 \%$. Lau (2008) was define the best cut off value of S. ferritin in discrimination of HCC cases was $=240$, sensitivity $=98 \%$ and specificity of $99 \%$.

\section{CONCLUSION}

Low level of serum iron were observed in chronic hepatitis $\mathrm{C}$, cirrhotic and HCC patients when compared to healthy individuals

Level of serum ferritin was highly significant increased in cirrhotic and HCC patients when compared to healthy individuals.

Level of serum hepcidin was highly significant decreased in cirrhotic and HCC patients when compared to healthy individuals.

There was negative correlation of serum hepcidin with s. ferritin in different studied patient groups.

\section{REFERENCES}

1. Gower E, Ester C, Blash S et al. (2014): Global epidemiology and genotype distribution of the hepatitis C virus infection. J Hepatol., 61:45-57.

2. El-Zanaty F and Way A (2008) : Egypt Demographic and Health Survey . https://dhsprogram.com/pubs/pdf/fr220/fr220.pdf

3.Silva P, Hiam $C$ and Laith $\mathbf{J}(2018)$ : Characterizing hepatitis C virus epidemiology in Egypt: Systematic reviews, meta-analysis and meta regression. Scientific Reports., 8: 1661.

4.Reddy KR (2015): Hepatitis C virus: The Next Epidemic. An Issue of Gastroenterology Clinics of North America, $1^{\text {st }}$ Edition book. www. Gastro. Theclinics.com.

5.Kim Y, Ejaz A, Tayal A et al. (2014): Temporal trends in population - based death rates associated with chronic liver disease and liver cancer in the united states over the last $30 \mathrm{y}$. cancer, 120:3058 -65. 
6.Singh S, Roberts LR, Sanchez W et al. (2014): Chemopreventive strategies in hepatocellular carcinoma. Nat Rev., 11(1):45-54.

7.Lehman EM and Wilson ML (2009): Epidemiology of hepatitis viruses among hepatocellular carcinoma cases and healthy people in Egypt: a systematic review and meta-analysis. Int J cancer, 124(3):690-7.

8.Park CH, Valore EV, Waring AJ et al (2001): Hepcidin, a urinary antimicrobial peptide synthesized in the liver. J Biol Chem., 276: 7806- 10.

9.Kuston MD, Oukka M, Koss LM et al (2005): Iron release from macrophages after erythrophagocytosis is up-regulated by ferroportin 1 over expression and down-regulated by hepcidin. ProcNatlAcadsci USA., 102:1324-8.

10.Ganz T and Nemeth $\mathbf{E}$ (2006): Iron imports IV: Hepcidin and requlation of body iron metabolism. Am J physiol. Gastrointestinal liver physiol., 290 (2):G199-G203.

11.Pietrangelo A and Trautwein C (2004): Mechanism of disease: The role of hepidin in iron homeostasisimplications for hemochromatosis and other disorder. Nat chin PracGostroenterologyHepatol., 1:39-45.

12.Mitsuyoshi H, Yasui K, Yamaguchi K et al. (2013): Pathogenic role of iron deposition in reticulendothelial cells during the development of chronic hepatitis C. Int J Heptol., 2013: 68620686428.

13. Bonkovsky HL (2002): Iron as acomorbid factor in chronic viral hepatitis. Am J Gastroenterol., 97(1):133-137.

14.Petruzziello A, Marigliano S, Loquercio G et al. (2016): Global epidemiology of hepatitis Cvirus infection: An up-date of the distribution and circulation of hepatitis Cvirus genotype, World $\mathbf{J}$ Gastroentrol.,22(34): 7824-7840.

15.Zou DM and Sun WL (2017): Relationship between Hepatitis C virus infection and iron overload. Chinese Medical Journal,130(7):866-871.

16.Bridle K, Cheung TK, Murphy $\mathbf{T}$ et al .(2006):Hepcidin is down-regulated in alcoholic liver injury: implications for the pathogenesis of alcoholic liver disease. Alcohol ClinExp Res., 30:106-12.

17.Nishina S, Hino $\mathrm{K}$, Korenaga $\mathrm{M}$ et al. (2008): Hepatitis $\mathrm{C}$ virus-induced reactive oxygen species raise hepatic iron level in mice by reducing hepcidin transcription. Gastroenterology, 134:226-38.

18.Marzouk HA, Zayed NA, Al-Ansary M et al. (2013): Hepcidin levels in Egyptian patients with chronic hepatitis $\mathrm{C}$ and the effect of anti-viral therapy. World Applied Sciences Journal, 22(8):1140-1145.
19.El Lehleh AM, El Shazly RA and Hamza RR (2017): Study of serum hepcidin in patients with chronic heoatitis C. Menoufia Medical Journal, 30(3):721-726.

20.Fujita N, Sugimoto R, Motonishi S et al. (2008): Patients with chronic hepatitis $\mathrm{C}$ achieving a sustained virological response to peginterferon and ribavirin therapy recover from impaired hepcidin secretion. J Hepatol., 49: 702- 10.

20.Mohamed FS, Elkady MM, El-Fedawy M et al. (2014): Study of serum hepcidin, iron and ferritin in chronic hepatitis $\mathrm{C}$ patients.American Journal of Medicine and Medical Sciences,4(6):283-286.

21.Oikonomou T, Goulis L, Cholongitas E et al. (2017): High serum ferritin is associated with worse outcomes of patients with decompensated cirrhosis. Annals of Gastroenterology, 30(2): 217-224.

22.Finkenstedt A, Krapf S, Vogel W et al. (2016): The iron score is an Meld-independent predictor of survival in patients with liver cirrhosis. Journal of Hepatology, 64(2):S443.

23.Pietrangelo A, Cohen LA, Waidmann O et al. (2015): Reply to: Ferritin in decompensated cirrhosis: iron or inflammation. Journal of Hepatology, 62:492-501.

24.Tawfik NM, Hegazy MA, Maksoud IA et al. (2012): Iron load and serum hepcidin in hepatitis $C$ virus-related hepatocellular carcinoma. Euroasian J Hepato-Gastroenterol.,2(1):24-27.

25.Mohamed A, Badawy I, El Amir N et al. (2014): Evaluation of serum hepcidin and iron levels in some liver disease. Middle East Journal Of Applied Sciences, 4(2):166-174.

26.Terrence CH, Darreell HG, Michael E et al .(2012): The serum hepcidin: ferritin ratio is a potential biomarker for cirrhosis. Liver International., 32(9):1391-1399.

27.Ryan J, Chiin JL, Crowe J et al. (2015): Ferritin in decompensated cirrhosis: iron or inflammation. Journal of Hepatology, 62(2):499-500.

28.El Wakil R, Mokhles M, Tohamy A et al. (2012):Hepcidin and chronic hepatitis $C$ virus: Exploring the controversy. Australian Journal of Basics and Applied Science, 6(13): 558-565.

29.Girelli D, MichelaPasino, Julia B et al.(2009):Reduced serum hepcidin levels in patients with chronic hepatitis C Journal of Hepatology ,51: 845-52. 